\title{
Tłumaczenia literatury litewskiej w publikacjach olsztyńskiego wydawnictwa „Pojezierze”
}

Streszczenie: Artykuł opowiada o dziejach Wydawnictwa Stowarzyszenia Społeczno-Kulturalnego „Pojezierze”, funkcjonującego w latach 1957-1991, w których kluczową rolę jako kierownik i redaktor naczelny odgrywał Andrzej Wakar. Instytucja ta przyczyniła się do rozpowszechnienia w Polsce wiedzy o literaturze litewskiej dzięki publikacji tłumaczeń takich dzieł, jak Mahoniowy raj (lit. Raudonmedžio rojus) Vytautasa Sirijos-Giry, Pory roku (lit. Metai) Kristionasa Donelaitisa, Borek oniksztyński (lit. Anykščiu šilelis) Antanasa Baranauskasa oraz antologii opowiadań pt. Wiecznie zielony klon.

Słowa-klucze: Wydawnictwo „Pojezierze”, Andrzej Wakar, literatura litewska, tłumaczenia

\section{Translations of Lithuanian literature in the publications of the Olsztyn publishing house "Pojezierze"}

Summary: The article outlines the history of the Publishing House of SocioCultural Association "Pojezierze", operating in the years 1957-1991, in which Andrzej Wakar played a key role as the head and editor-in-chief.

Marcin Wakar - doktor nauk humanistycznych; urodzony w 1976 roku w Olsztynie; absolwent filozofii na Uniwersytecie Mikołaja Kopernika w Toruniu, doktorat z zakresu nauk humanistycznych (socjologia polityki) obronił na Wydziale Dziennikarstwa i Nauk Politycznych Uniwersytetu Warszawskiego; pracował m. in. w Ośrodku Badań Naukowych im. W. Kętrzyńskiego w Olsztynie oraz w Studium Europy Wschodniej Uniwersytetu Warszawskiego.. 
This institution contributed to the dissemination of knowledge about Lithuanian literature in Poland thanks to the publication of translations of works such as Raudonmedžio rojus [TN: Mahogany Paradise] by Vytautas Sirijos-Giry, Metai [TN: The Seasons] by Kristionas Donelaitis, Anykščiu šilelis [TN: Anykščiu Manor] by Antan Baranauskas and an anthology of stories entitled The Evergreen Maple.

Key words: “Pojezierze” publishing house, Andrzej Wakar, Lithuanian literature, translation

\section{Lietuvių literatūros vertimai Olštyno leidykloje „Pojezierze“}

Pranešimo santrauka: Pradžioje pranešimo „Lietuvių literatūros vertimai Olštyno leidykloje »Pojezierze«" autorius trumpai pristatys Olštyno leidyklos, vienos didžiausių regioninių leidyklų Lenkijoje, veikiančių 1956-1991 metais, istoriją. Toliau bus aptartas bendradarbiavimas leidyklos „Pojezierze“ su Lietuva, o tiksliau su Vilniaus leidyklomis „Vaga”, „Mintis”, „Vyturys”, „Mokslas” ir Kauno „Šviesa”. Pagrindinèje pranešimo dalyje bus nagrinèti lietuvių literatūros vertimai, išleisti Olštyno leidykloje: Antano Baranausko „Anykščiu šilelis", Kristijono Donelaičio „Metai“, Vytauto Sirijos-Giros „Raudonmedžio rojus“ ir kt. Autorius taip pat trumpai pristatys vertèjus, kurių darbo dèka minètos knygos galèjo būti išleistos lenkų kalba.

Raktiniai žodžiai: Leidykla "Pojezierze”, Andrzej Wakar, lietuvių literatūra, vertimai.

W końcu lat siedemdziesiątych XX wieku - jak wspominał rutenista, lituanista, były Konsul Generalny RP w Wilnie, prof. dr hab. Mieczysław Jackiewicz ${ }^{1}$ Ministerstwo Kultury i Sztuki zadecydowało o specjalizacji wydawnictw regionalnych w przekładach literatur obcojęzycznych. Tłumaczenia literatury białoruskiej przydzielono wówczas Wydawnictwu Łódzkiemu, skandynawskiej Wydawnictwu Poznańskiemu, a litewskiej olsztyńskiemu Wydawnictwu „Pojezierze”2.

1 Rozmowa z prof. dr. hab. Mieczysławem Jackiewiczem przeprowadzona przez autora 5 października 2017 r. w Ośrodku Badań Naukowych im. W. Kętrzyńskiego w Olsztynie.

2 W „Pojezierzu” również wydawano literaturę z innych krajów ZSRR, w tym z Łotwy, Estonii i Białorusi. 
Ta początkowo niewielka oficyna powstała na kanwie przemian politycznych, jakie miały miejsce w Polsce w październiku 1956 roku. Wówczas w kręgu olsztyńskich dziennikarzy i działaczy kultury zawiązała się idea powołania stowarzyszenia społeczno-kulturalnego, którego celem było między innymi wydawanie książek, głównie o tematyce regionalnej. Utworzenie Działu Wydawniczego uchwalono na zebraniu Zarządu Głównego 17 lutego 1957 roku, a zatem jeszcze przed zatwierdzeniem statutu organizacji, co miało miejsce ponad miesiąc później³ ${ }^{3}$ Ostatecznie przyjęto nazwę Stowarzyszenie Społeczno-Kulturalne „Pojezierze”. W pierwszych trzech latach udało się wydać 25 pozycji książkowych o łącznym nakładzie 145400 egzemplarzy4 ${ }^{4}$ Kolejni kierownicy Działu podnosili poziom edytorski publikacji, jednak wciąż Zarząd Główny nie był zadowolony z funkcjonowania oficyny. Do przełomu doszło 16 marca 1966 roku, kiedy na stanowisko kierownika i redaktora naczelnego wybrano historyka i publicystę Andrzeja Wakara. Po kilkuletnich staraniach doprowadził on w 1973 roku do wyodrębnienia ze stowarzyszenia przedsiębiorstwa o nazwie Wydawnictwo SSK „Pojezierze”5, które formalnie pozostawało własnością organizacji i miało jej przekazywać $40 \%$ zysków. Polityka redakcyjna Wakara pozytywnie wpłynęła na rozwój Wydawnictwa, które na przełomie lat 70. i 80. XX wieku wprowadzało na rynek księgarski od dwudziestu do pięćdziesięciu tytułów rocznie ${ }^{6}$.

Po wspomnianej już decyzji Ministerstwa Kultury i Sztuki, Andrzej Wakar - ówczesny dyrektor Wydawnictwa „Pojezierze”, poprosił Mieczysława Jackiewicza, żeby przeczytał trzy nadesłane książki, wśród których był Mahoniowy raj (lit. Raudonmedžio rojus) Vytautasa Sirijos-Giry. Ta pozycja wydała się Jackiewiczowi najbardziej interesująca i na prośbę dyrekcji wydawnictwa podjął się jej tłumaczenia. Wspominał, że było to zadanie niełatwe, ze względu na niewystarczającą wówczas znajomość języka litewskiego 7 .

3 M. Jackiewicz, Stowarzyszenie Społeczno-Kulturalne „Pojezierze”. XXX lat działalności 1956-1986, Olsztyn 1986, s. 35.

4 Katalog Wydawnictwa „Pojezierze” (1957-1982), oprac. S. Fafiński, Olsztyn 1983, s. 8.

5 Katalog Wydawnictwa ,Pojezierze” (1957-1976), oprac. I. Chomicka, Olsztyn 1977, s. 7.

6 Więcej na ten temat [w:] M. Wakar, Stowarzyszenie Społeczno-Kulturalne „Pojezierze" w latach 1956-1989, Olsztyn 2011.

7 Rozmowa z prof. dr. hab. Mieczysławem Jackiewiczem, dz. cyt. 
W międzyczasie zapadła też decyzja o tłumaczeniu Pór roku (lit. Metai) Kristionasa Donelaitisa. W tym przypadku przekładu podjął się Zygmunt Ławrynowicz. Ten pochodzący z Poniewieża poeta i eseista, na stałe mieszkający w Londynie, od lat najmłodszych biegle znał litewski ${ }^{8}$. Dlatego też tłumaczenie jego autorstwa ukazało się drukiem w olsztyńskiej oficynie jako pierwsze już w 1982 roku. Co ciekawe, koncesję na wydawanie thumaczeń literatury zjęzyków: białoruskiego, litewskiego i rosyjskiego Wydawnictwo „Pojezierze” otrzymało dopiero w 1985 roku', a zatem już trzy lata po wydaniu przekładu Donelaistisa.

Bez względu na brak koncesji twardo oprawiona książka, w nakładzie 4 tys. egzemplarzy, została opublikowana w wersji dwujęzycznej. Po lewej stronie można czytać oryginał litewski, po prawej zaś tłumaczenie. Poemat został poprzedzony szerokim wstępem, którego pierwszą część, zatytułowaną Litwa Pruska a Mazury, napisał historyk i naczelny redaktor wydawnictwa - Andrzej Wakar. Wprowadza ona (tj. pierwsza część wstępu) czytelnika $\mathrm{w}$ historyczne niuanse związane $\mathrm{z}$ faktem, iż jedno z czołowych arcydzieł literatury litewskiej ukazało się w Prusach Książęcych. Druga i trzecia część wstępu, autorstwa tłumacza Zygmunta Ławrynowicza dotyczy zarówno postaci Donelaitisa, jak i jego najważniejszego dzieła. Zwraca on w nim uwagę na fakt, iż pierwsze thumaczenie poematu na język polski, autorstwa Kazimierza Paszkiewicza, ukazało się jeszcze w 1933 roku w Warszawie i ponownie po dwudziestu latach w Wilnie ${ }^{10}$. Jednak, jak zauważa, dla Pietkiewicza oraz innych badaczy było to dzieło interesujące przede wszystkim pod względem etnograficznym i traktowano jej jako zabytek historyczny nieposiadający szczególnej wartości literackiej. Dlatego też jego przekład pełen jest opuszczeń, poprawek i przeredagowań, co spotkało się ze słuszną krytyką ze strony filologów litewskich ${ }^{11}$.

Zygmunt Ławrynowicz ,[...] przyjął zasadę, że utwór Donelaitisa nie może być poprawiany czy uzupełniany. Należało, jego zdaniem, dać możliwie

8 http://www.bu.kul.pl/zygmunt-lawrynowicz-poeta-eseista-tlumacz-emigrant,art 11277.html (logowanie: 10.10.2017 r.).

9 Faktycznie był to aneks do koncesji z 1972 r.; Archiwum Stowarzyszenia SpołecznoKulturalnego „Pojezierze” 2/3/10 - Aneks do koncesji nr 3/72 z 11.11.1985 r., s. 11.

10 Z. Lawrynowicz, Pory roku, [w:] K. Donelajtis, Pory roku, Olsztyn-Białystok 1982, s. XLIII.

11 Tamże. 
dokładną wersję oryginału. Tłumacz nie ma prawa być «belfrem» ani cenzorem, ani tym bardziej krzywym zwierciadłem. Dlatego prezentowany tu przekład jest nieomal dosłowną wersją oryginału idącą słowo w słowo za tekstem litewskiego poety. Ponieważ [stosowany przez Donelaitisa - przyp. autora] heksametr nie leży w duchu języka polskiego [...] należało go zastąpić trzynastozgłoskowcem, który posiada piękne prawa obywatelskie w polskiej mowie wiązanej. Rym, nieobecny w oryginale, został uznany za zbędny i kłopotliwy element ornamentacyjny, i jako taki skazany na banicję"12.

Ławrynowicz w thumaczeniu spolszcza imię litewskiego pastora i poety do brzmienia Krystyn. Jak thumaczył to wydawca: „Dla imienia Donelaitisa literatura litewska urobiła formę Kristionas, której w języku polskim odpowiada imię Krystyn, lepiej niż Chrystian. Tłumacz uznał formę «Krystyn» za najbardziej historycznie uzasadnioną. Imię Krystyn było w końcu XVIII wieku modne w Prusiech, niegdyś Książęcych (na przykład Krystyn Lach Szyrma, Krystyn Milkus i inni)"13.

Trzeba podkreślić, że było to dotąd ostatnie polskojęzyczne wydanie jednego z najważniejszych zabytków litewskiej literatury.

Jako druga ukazała się w 1986 roku wspomniana już powieść Vytautasa Sirijos-Giry Mahoniowy raj. Jak wspominał autor przekładu - Mieczysław Jackiewicz - język litewski znał wówczas jeszcze nienazbyt dobrze ${ }^{14} \mathrm{i}$ dopiero thumaczenie Mahoniowego raju wymogło na nim pogłębienie znajomości tego języka. Było w tamtym czasie problem z dostępnością do słowników litewskopolskich. W końcu udało mu się wypożyczyć, skopiować i oprawić słownik, który w jego bibliotece zajmuje poczesne miejsce do dziś. Mieczysław Jackiewicz sam zrobił tzw. rybkę, czyli przekład dosłowny. Literacko opracowała tekst jego córka, Wiesława Kalita. Nie dowiemy się o tym jednak ze strony tytułowej, gdyż ówczesny kierownik redakcji literatury pięknej, Jerzy Adam Sokołowski, stwierdził, iż musi to być znane nazwisko i jako tłumacz został wpisany jedynie Mieczysław Jackiewicz ${ }^{15}$.

12 Tamże, s. XLIV.

13 A. Wakar, Litwa Pruska a Mazury, [w:] K. Donelajtis, Pory roku, Olsztyn-Białystok 1982, s. XXI.

14 Rozmowa z prof. dr. hab. Mieczysławem Jackiewiczem.

15 Tamże. 
Mahoniowy raj to, w zasadzie, powieść o charakterze uniwersalnym. Tematem przewodnim jest dojrzewanie, pierwsze relacje z kobietami i męska przyjaźń ucznia, studenta i w końcu lekarza Karolisa Tuleikisa. Akcja toczy się głównie w przedwojennym Kownie i okolicach. Powieść jest ciekawym obrazem litewskiego społeczeństwa okresu dwudziestolecia międzywojennego i czasów II wojny światowej. W książce pokazano także dynamiczne przemiany cywilizacyjne samego Kowna, które było wówczas tzw. tymczasową stolicą Litwy. Syrijos-Gira z dużą wrażliwością stworzył postać głównego bohatera i gdy czyta się tę książkę, robi się żal, że współcześnie jest już ona praktycznie zapomniana ${ }^{16}$.

Jest to jednak powieść, która ukazała się po raz pierwszy w stolicy radzieckiej Litwy w 1978 roku. Dlatego też, choć pobocznie, pojawia się element komunistycznej walki rewolucyjnej z nacjonalistycznym reżimem Antanasa Smetony. Tuleikis, choć apolityczny, pomaga w tej walce, przechowując i dostarczając paczki, które w tajemnicy przekazuje mu kolega z medycyny o nazwisku Starkus. Sam przez to trafia w ręce służby bezpieczeństwa, jednakże nic nie można mu udowodnić i wychodzi z więzienia po kilku dniach. Silnie pobity, lecz żywy.

Książka składa się z trzech części i epilogu. Wszystkie mają jako tytuł żeńskie imię: Wikte, Anita, Irena i Epilog albo Aldona-Julia. Niestety, w przeciwieństwie do pozostałych przekładów z języka litewskiego, które ukazały się nakładem Wydawnictwa „Pojezierze”, ta publikacja nie została opatrzona wstępem, czy choćby notą biograficzną o autorze.

Po wydaniu tych dwu tytułów Litwini zainteresowali się poszerzeniem współpracy z olsztyńską placówką wydawniczą, czego dowodem były spotkania, jakie odbywały się między polskimi i litewskimi wydawcami. Gdy Olsztyn odwiedził Wadim Dunin - stały przedstawiciel Wszechzwiązkowej Agencji Praw Autorskich Związku Radzieckiego w PRL, w wywiadzie dla „Gazety Olsztyńskiej" powiedział:

Znam »Pojezierze« od lat. Mamy kilka umów z wydawcami na druk literatury litewskiej, »Pojezierze« korzysta z tzw. poszerzonej licencji na tego typu działalność edytorską. Dwa lata temu na Litwie odbyło się spotkanie wydawców z innych krajów

16 Autor niniejszego opracowania wypożyczył Mahoniowy Raj w olsztyńskiej Wojewódzkiej Bibliotece Publicznej. Nie nosił on śladów czytania. 
interesujących się książkami o Litwie i litewskimi pisarzami. Na tym spotkaniu obecni byli przedstawiciele »Książki i Wiedzy«, PIW-u [Państwowego Instytutu Wydawniczego - przyp. M.W.], a także »Pojezierza«, którzy przywieźli konkretne propozycje. Okazało się, że od tamtego czasu już je w dużym stopniu zrealizowali. [...] Osobiście jestem bardzo zainteresowany tym, co już olsztyńskie wydawnictwo zrobiło w propagowaniu literatury litewskiej, białoruskiej i radzieckich republik nadbałtyckich ${ }^{17}$.

W grudniu 1986 roku przedstawiciele „Pojezierza” odwiedzili Wilno i Kowno, gdzie rozmawiali z szefami wydawnictw: „Mintis”, „Mokslas”, „Vaga”, „Vyturys” i „Šviesa”. Te spotkania stworzyły dobrą atmosferę do opracowania kolejnych przekładów.

Trzecią książką przetłumaczoną z języka litewskiego i opublikowaną przez „Pojezierze” był znów klasyczny utwór litewskiej literatury narodowej. Tym razem sięgnięto po Borek oniksztyński (lit. Anykščiu šilelis) Antanasa Baranauskasa, który ukazał się w 1987 roku w nakładzie 2 tys. egzemplarzy. Podobnie jak Pory roku został wydany dwujęzycznie. Autorami przekładu byli Józef Wajna, a właściwie Juozo Vainos, Litwin z Puńska, oraz olsztyński poeta Józef Jacek Rojek. Warto zwrócić uwagę, że jako miejsce wydania podano: Olsztyn-Białystok. Związane było to z faktem, iż w rozwijającym się Wydawnictwie w 1975 roku podjęło decyzję o utworzeniu filii w Białymstoku. Choć po kilku latach uległa ona likwidacji, to jeszcze przez wiele lat na stronach tytułowych widniało podwójne miejsce wydania, które nie odzwierciedlało stanu faktycznego ${ }^{18}$.

Był to drugi pełny przekład Borku oniksztyńskiego na język polski. Pierwszego dokonała w 1909 roku wileńska poetka Stefania Jabłońska. Fragmenty w latach trzydziestych XX wieku przetłumaczyła również Julia Wichert-Kajruksztisowa. O wydaniu nowego thumaczenia zadecydowała dyrekcja Wydawnictwa „Pojezierze”. Tomik opublikowany w olsztyńskiej oficynie opatrzony został szerokim wstępem przez wspominanego już Mieczysława Jackiewicza. Zawarł w nim zarówno biografię księdza-poety Antanasa Baranauskasa, jak również analizę literacką samego utworu. W swym wprowadzeniu Jackiewicz zwraca

17 TMK, Z Wadimem Duninem o książkach „Pojezierza”, „Gazeta Olsztyńska” 1986, nr 123, s. 4.

18 A. Wakar, Bialystok $i$ „Pojezierze”, „Kontrasty” 1979, nr 3, s. 62. 
uwagę na silny wpływ Mickiewicza i Słowackiego na autora Borku, w szczególności zaś Pana Tadeusza, który stał się dla Baranauskasa głównym impulsem do napisanie swego poematu. Autor Borku chciał przez swoje dzieło udowodnić, że język litewski jest wystarczająco bogaty w środki artystyczne, by można stworzyć w nim epopeję na miarę wspomnianego dzieła Mickiewicza ${ }^{19}$.

O samym utworze napisał Mieczysław Jackiewicz we wstępie:

Borek oniksztyński jest w pełni poematem romantycznym i według ogólnej koncepcji, potwierdzającej piękno wolności, i według gatunku jako utwór liryczny. Linie tematyczne przeplatają się z tematami lirycznymi - piękno starych lasów i ich losy, historia kraju ojczystego i przyszłość narodu. Wstęp, w którym zawarty jest motyw współczesności, wyraźnie rozgranicza się od części podstawowej - lirycznych wspomnień, rozmyślań w pierwszej połowie poematu i epickiego przedstawienia legend, podań i faktów historycznych w drugiej ${ }^{20}$.

Trzeba dodać, że poemat został wydany pod polską wersją nazwiska autora: Antoni Baranowski.

Jako ostatnia książka thumaczona z języka litewskiego ukazała się w 1990 roku antologia opowiadań pt. Wiecznie zielony klon. Zbiór wydano w nakładzie 4,5 tys. egzemplarzy. Na 373 stronach znalazło się aż 40 opowiadań i nowel, każda innego autorstwa, dzięki czemu polski czytelnik miał szansę poznać szeroki przekrój litewskiego środowiska literackiego z końca XIX i ośmiu dekad XX wieku²1. Każdy z tekstów poprzedzony został biogramem

19 M. Jackiewicz, Borek oniksztyński, [w:] A. Baranowski, Borek oniksztyński, OlsztynBiałystok 1987, s. XXIX- XXX.

20 Tamże, s. XXXV.

21 W antologii ukazały się następujące opowiadania (kolejność, jak w książce): Žemaite, Pojmany bies (Sučiuptas velnias); Antanas Krikščiukaitis-Aišbè, Bryczka (Brička); Jonas Biliūnas, Gwiazda (Žvaigždè); Gabrielè Petkavičaitè-Bitè, Matpka (Bezdžionaitė); Konstantinas Jasiukaitis, Na bulwarze (Bulvare); Lazdynu Pelèda, Krzywda (Skriauda); Vaižgantas, Jaki ze mnie bohater (Koks iš mane didvyris); Jurgis Savickis, Złodziej (Vagis); Šatrijos Ragana, Tragedia Irki (Irkos tragedija); Kazys Kiela, Posag (Dalis); Petras Cvirka, O tym, jak Vincelis gwizdaniem przywołał diabła (Prišvilptas velnias); Juozas Grušas, Dogasająca świeca (Uždegusi žvake); Ieva Simonaityte, Kryzys (Krizė); Vincas Žilionis, Rosa opadała (Krito rasa); Kazys Jankauskas, Zamknięta szopa (Užkantas sandelis); Augustinas Gricius, Zdarzenie w wagonie(Jvykis vagone); Antanas Vienuolis, Źrebak mojego chrzestnego (Kumeliukas mano krikšto tevo); Jonas Šimkus, Foka (Ruonis); Ju- 
autora. Wyboru opowiadań dokonał Mieczysław Jackiewicz. Również on poprzedził książkę wstępem oraz wszystkie opowiadania krótkimi biogramami autorów. Jest też autorem większości tłumaczeń. Podobnie, jak w przypadku Mahoniowego raju, Wiesława Kalita (tym razem widnieje na stronie tytułowej jako współautorka przekładów) opracowała literacko jego dosłowne tłumaczenia. Jedno z opowiadań, Jaki ze mnie bohater (lit. Koks iš mano didvyris) Vaižgantasa, przetłumaczyła Barbara Kaleda.

Całość antologii podzielona została na trzy części: Opowiadania końca XIX i początku XX wieku. 1880-1917; Opowiadania okresu międzywojennego. 1918-1940 oraz Opowiadania okresu radzieckiego. 1941-1980. W pierwszej zaprezentowani zostali autorzy nurtu realizmu krytycznego, między innymi Žemaitè - czyli Julija Beniuševičiūté-Žymantienè z opowiadaniem Pojmany bies (lit. Sučiuptas velnias), Jonas Biliūnas z Gwiazda (lit. Žvaigžde) oraz Konstantinas Jasiukaitis z nowelą Na bulwarze (lit. Bulvare). O tym nurcie w literaturze napisał Mieczysław Jackiewicz:

W prozie litewskiego realizmu krytycznego, poruszającej problemy ruchu narodowościowego, ujęcie koncepcji świata i człowieka było jeszcze nieskomplikowane, natomiast bardziej złożoną interpretację dostrzec można w nurcie prozy o problematyce społecznej. Proza ta motywuje zmiany zachodzące w człowieku różnymi uwarunkowaniami społecznymi, materialnymi, klasowymi i moralnymi ${ }^{22}$.

ozas Balyušis, Ostatnia łagodna radość (Paskutinis tylus džiaugsmas); Antanas Venclova, Śmierć w Lizbonie (Mirtis Lisabonoj); Aleksandras Bauža, Nóż fiński (Suomiškas peilis); Viktoras Miliūnas, Deszczowy poranek (Lietingas rytas); Vytautas Sirijos-Gira, Amulet (Amuletas); Jonas Avyžius, Śwniobicie (Skerstuves); Jonas Mikelinskas, Męczące oczekiwanie, czyli studnia (Sunkus laukimas, arba Šulinys); Mykolas Sluckis, Niedziela dla dziewcząt (Merginų sekmadienis); Vytautas Bubnys, $W$ czwartek o godzinie trzeciej (Ketvirtadienį, trečia valanda); Vladas Dautartas, W krainie moich marzeń (Mano svajonių kraštas); Juozas Aputis, Zielony pociag (Žalias traukinys); Algirdas Pocius, Eksponat (Eksponatas); Vytautė Žilinskaitė, O odznaczeniach (Romantikos institutas); Vytautas Rimkevičius, Do Afryki na lwy (I Afriką, liutų...); Romualdas Lankauskas, Pustynia (Dykuma); Kazys Saja, Kamień Syzyfa (Sizifo akmuo); Vytautas Martinkus, Biblia dla ubogich (Vargšų biblija); Povilas Dirgėla, Petras Dirgèla, Płacz dziecka (Berniuko verksmas); Bronius Radzevičius, $W$ stronę Debesji (Link Debesijos); Rimantas Šavelis, Temat $z$ wariacjami (Tema su variacijomis); Saulius Šaltenis, Wiecznie zielony klon (Amžinai žaliojantis klevas); Danielius Mušinskas, Stuchacze wiecznej muzyki (Amžinos muzikos klausytojai).

22 M. Jackiewicz, Opowiadanie na tle rozwoju literatury litewskiej, [w:] Wiecznie zielony klon, red. M. Jackiewicz, Olsztyn 1990, s. VI. 
Opowiadania okresu międzywojennego to już nowe pokolenie pisarzy i powstające obok realizmu krytycznego nowe nurty w literaturze. Wśród autorów tej części antologii odnaleźć można takich prozaików jak: Juozas Grušas z opowiadaniem Dogasająca świeca (lit. Uždegusi žvakè), pochodząca z Prus Wschodnich Ieva Simonaitytė z Kryzysem (lit. Krizè), Šatrijos Ragana z Tragedia Irki (lit. Irkos tragedija), czy Kazys Jankauskas z opowiadaniem Zamknięta szopa (lit. Užkaltas sandèlis). Zwłaszcza w twórczości dwóch ostatnich odnaleźć można cień wpływów modernistycznych, głównie impresjonizmu.

Ostatnia, najbogaciej reprezentowana, jest literatura okresu radzieckiego. Choć wszystkie dwadzieścia pięć opowiadań i nowel utrzymanych jest w nurcie realizmu socjalistycznego, to w części tej przedstawiono prozaików kilku pokoleń, posiadających różną wrażliwość artystyczną. I tak znaleźć możemy między innymi opowiadanie Augustinasa Griciusa Zdarzenie w wagonie (lit. Ivykis vagone) z 1944 roku i wspomnianego już wcześniej Vytautasa SirijosGiry Amulet (lit. Amuletas) z 1971 roku. Jest też tekst Jonasa Avyžiusa:

[...] który wzbogacił nowelistykę obrazami «nieupiększonej» rzeczywistości kołchozowej. Nie unikając publicystyki i szkicowości, pisarz ujawnił w opowiadaniach wiele niedorzecznych zjawisk życia na wsi kołchozowej, na przykład Skerstuvès (Świniobicie, 1955), wobec których pisarze wcześniej opuszczali wstydliwie oczy albo uważali je za nietypowe i nie zasługujące na uwagę $e^{23}$.

Obok wspomnianych znaleźć można jeszcze opowiadania i nowele Vytautasa Bubnysa, Romuladasa Lankauskasa, Juozasa Aputisa i wielu innych.

Antologia Wiecznie zielony klon była ostatnią książką thumaczoną z litewskiego, jaką wydało Wydawnictwo „Pojezierze”. I jedną z ostatnich pozycji opublikowanych przez olsztyńską oficynę w ogóle. Wydawnictwo „Pojezierze" upadło w 1991 roku. Jak skomentował to olsztyński historyk, prof. Bohdan Łukaszewicz:

Kiedy A. Wakar odchodził na emeryturę [w 1987 roku - przyp. autora], nikt nie spodziewał się, że tak świetnie prosperująca oficyna zakończy swój żywot, tym 
bardziej, że rok 1989 przyniósł wydarzenia usuwające dotychczasowe bariery i hamulce. Egoizm jednostki, walka o schedę po Wakarze doprowadziły ostatecznie do likwidacji tej zasłużonej dla olsztyńskiej humanistyki placówki24.

Wyjątkowy splot wydarzeń, jakim nazwać można oddolną inicjatywę powołania w stosunkowo niewielkim mieście dużego wydawnictwa książkowego i nawiązanie z nim współpracy wychowanego w Wilnie filologa - Mieczysława Jackiewicza, sprawił iż Olsztyn zdecydowanie wyróżnił się na mapie wydawniczej ówczesnej Polski. Tylko Wydawnictwo „Pojezierze” podjęło się przygotowania i druku tłumaczeń dwu nestorów poezji litewskiej: Kristionasa Donelaitisa i Antanasa Baranauskasa. Tylko dzięki wydanej w „Pojezierzu” antologii Wiecznie zielony klon i powieści Mahoniowy raj polski czytelnik mógł poznać szeroki przekrój litewskiej prozy. Można dziś jedynie przypuszczać, że gdyby Wydawnictwo funkcjonowało dłużej, pojawiłyby się kolejne przekłady, w tym przede wszystkim innego klasyka litewskiej poezji - Jonasa Mačiulisa, znanego pod pseudonimem Maironis.

\section{Bibliografia}

http://www.bu.kul.pl/zygmunt-lawrynowicz-poeta-eseista-tlumacz-emigrant,art_ 11277.html (logowanie: 10.10.2017 r.).

Jackiewicz M., Borek oniksztyński, [w:] A. Baranowski, Borek oniksztyński, OlsztynBiałystok 1987.

Jackiewicz M., Opowiadanie na tle rozwoju literatury litewskiej, [w:] Wiecznie zielony klon, red. M. Jackiewicz, Olsztyn 1990.

Jackiewicz M., Stowarzyszenie Społeczno-Kulturalne „Pojezierze”. XXX lat działalności 1956-1986, Olsztyn 1986.

Katalog Wydawnictwa „Pojezierze” (1957-1976), oprac. I. Chomicka, Olsztyn 1977.

Katalog Wydawnictwa „Pojezierze” (1957-1982), oprac. S. Fafiński, Olsztyn 1983.

24 B. Łukaszewicz, Olsztyn w Polsce Ludowej, [w:] Olsztyn 1353-2003, pod red. S. Achremczyka i W. Ogrodzińskiego, Olsztyn 2003, s. 471. 
Ławrynowicz Z., Pory roku, [w:] K. Donelajtis, Pory roku, Olsztyn-Białystok 1982.

Łukaszewicz B., Olsztyn w Polsce Ludowej, [w:] Olsztyn 1353-2003, pod red. S. Achremczyka i W. Ogrodzińskiego, Olsztyn 2003.

TMK, Z Wadimem Duninem o książkach „Pojezierza”, "Gazeta Olsztyńska” 1986, nr 123.

Wakar A., Białystok i „Pojezierze”, „Kontrasty” 1979, nr 3.

Wakar A., Litwa Pruska a Mazury, [w:] K. Donelajtis, Pory roku, Olsztyn-Białystok 1982 .

Wakar M., Stowarzyszenie Społeczno-Kulturalne „Pojezierze” w latach 1956-1989, Olsztyn 2011. 